\title{
Longshore sediment transport on the Brazilian Continental Shelf
}

\author{
Transporte longitudinal de sedimentos na Plataforma Continental Brasileira
}

\author{
T. B. Trombetta ${ }^{1 *}$; W. C. Marques ${ }^{1}$; R. C. Guimarães ${ }^{1}$; E. P. Kirinus ${ }^{1}$; D. V. Silva ${ }^{1}$; \\ P. H. Oleinik ${ }^{1}$; T. L. Fagundes ${ }^{1}$; L. A. Isoldi ${ }^{2}$ \\ ${ }^{1}$ Laboratório de Análise Numérica e Sistemas Dinâmicos - LANSD, Universidade Federal do Rio Grande, 96203-900, \\ Rio Grande-RS, Brasil \\ ${ }^{2}$ Escola de Engenharia, Universidade Federal do Rio Grande, 96203-900, Rio Grande-RS, Brasil \\ *thaisa_bt@hotmail.com
}

\begin{abstract}
As praias estão constantemente sofrendo alterações morfológicas devido à interação entre componentes energéticos e desequilíbrios no suprimento sedimentar local. O clima de ondas é a principal variável indutora dos processos costeiros de médio e curto prazo, responsável pelo transporte transversal e longitudinal de sedimentos. Sendo assim, o conhecimento prévio do clima ondulatório local representa uma fonte de informação essencial para a elaboração de planos de gerenciamento costeiro. Inserido neste contexto, o presente trabalho tem como finalidade estimar o transporte longitudinal de sedimentos $(T L S)$ em diferentes setores da costa brasileira, identificando as médias anuais e o sentido predominante do transporte. O estudo foi realizado para o período compreendido entre os anos de 1979 e 2015, utilizando a modelagem computacional para investigar o comportamento das ondas, e formulações empíricas para calcular as taxas de $T L S$. Os resultados mostraram uma grande diversidade no comportamento do clima ondulatório ao longo de toda a costa brasileira, apresentando boa correlação em termos de ordens de grandeza entre as estimativas do $T L S$ e estudos pretéritos nos diferentes trechos analisados. O local onde o transporte apresentou-se bastante acentuado compreende a Região Nordeste, especificamente entre a Bahia e Sergipe, e as menores, na Região Sudeste e na parte sul da Bahia. O sentido da deriva litorânea, majoritariamente acarretado pela ação das ondas, foi direcionado para Sul no trecho entre o Rio de Janeiro e a Bahia e em algumas regiões de Sergipe. Já o transporte para o Norte compreende as regiões Sul e Sudeste, assim como uma zona considerável do Nordeste e toda a Região Norte. Neste sentido, são disponibilizadas informações relacionadas ao comportamento das ondas e do transporte sedimentar ao longo de toda a costa brasileira, diferentemente dos estudos disponíveis na literatura que são realizados de forma pontual e abordam somente regiões específicas. Dessa forma, os resultados apresentados neste trabalho podem ser considerados em futuros projetos de engenharia, que envolvam a gestão e o manejo sustentável da zona costeira.
\end{abstract}

Palavras-chave: Zona costeira. Ondas. Sedimentos. Kamphuis.

Beaches are suffering morphological changes due the interaction between energetics components and local sedimentary supply imbalance. The understanding of the wave climate is an essential source of information for the composition of coastal planning projects. The main goal of this work is to estimate the longshore sediment transport (LST) in various sectors of the Brazilian Coast, and to identify the annual average and its dominant direction. For this study was considered the period between 1979 and 2015, applying computational modeling to investigate the waves behavior, and empirical formulas to calculate LST rates. The results showed a great discrepancy in the wave climate along the Brazilian Coast, and presented similarities rates between the estimation of LST and previous studies for different sectors analyzed. The sector where transport rates have been higher understanding the Northeast region, specifically between Alagoas and Rio Grande do Norte states. The opposite of it was observed in the Southern part of Bahia. The dominant direction of sediments, mainly caused by the waves, was directed to South between Rio de Janeiro and Bahia states, and in some parts of Sergipe. Transportation to the north comprises the South and Southeast regions, as well as a considerable area of the Northeast and the entire Northern Region. In this sense, information related to wave behavior and sediment transport along the Brazilian Coast is presented, unlike studies available in the literature that are carried out locally and approach only specific regions. Thus, the results presented can be considered in future projects, involving the sustainable management of coastal zones.

Keywords: Coastal zone. Waves. Sediment. Kamphuis. 


\section{INTRODUCTION}

The longshore sediment transport (LST) is an important factor related with morphological changes in coastal areas. The lack of planning and management in relation to the transport of sediments, whether by natural or man-induced causes, can change the equilibrium in coastal regions in the short or long term. The knowledge of local wave climate and LST rates represent an essential source of information for project design, coastal management plans and applications of risk analysis in relation to erosion.

In Brazil, the situation of coastal zones in relation to erosion is not different from most countries, since there are numerous beaches where the process is quite severe [1] and requires emergency measures of containment and/or recovery [2]. The Ministério do Meio Ambiente (MMA) and the Grupo de Articulação e Integração do Gerenciamento Costeiro (GAI-GERCO) have established preventive action plans in the coastal environment, highlighting territorial planning, coastal containment and protection, projects and scenario studies that can guide investments. Pitombeira (1973) [3] affirmed that the prior knowledge of how sediment transport behaves is of incalculable value in a marine engineering project; every maritime works designer would like to have a prediction of the coastal transport, so that he could guide his projects so as not to contradict them and thus avoid a series of undesirable disorders.

According to this subject, the present study consists to estimate the LST along the Brazilian Coast, identifying the annual averages rates and the predominant direction of sedimentary transport. Therefore, the wave climate in the Brazilian Continental Shelf was analyzed with the computational modeling of waves, and the LST was calculated with formulas proposed by Coastal Engineering Research Center - CERC (1984) [4] and by Kamphuis (1991) [5]. The most appropriate formula for each analyzed region was also defined, comparing the results of previous studies related to morphodynamic processes.

The study region comprises the Brazilian Continental Shelf, extending between the latitudes $34^{\circ}$ South and $4^{\circ}$ North, next to Chuí - (in Rio Grande do Sul state) and the Cabo Orange (in Amapá state), respectively. For the characterization of sedimentological data and to identify the median diameter of sediments $\left(\mathrm{D}_{50}\right)$, the Brazilian Coast was divided into four distinct sections, based on data derived from ReviZEE Program expeditions.

\section{MATERIALS AND METHODS}

In this study, the third-generation wave model TOMAWAC was applied to simulate the sea state throughout the Brazilian Continental Shelf. This model was initially developed by Benoit et al. (1996) [6], and is currently maintained as part of the open TELEMAC-MASCARET. The study encompassed a period of 37 years, between 1979 and 2015, with data saved daily. According to Figure 1, the spatial domain was represented by an unstructured mesh, with 547479 nodes and distance of $55 \mathrm{~km}$ in the oceanic region and $500 \mathrm{~m}$ in the coastal region. 

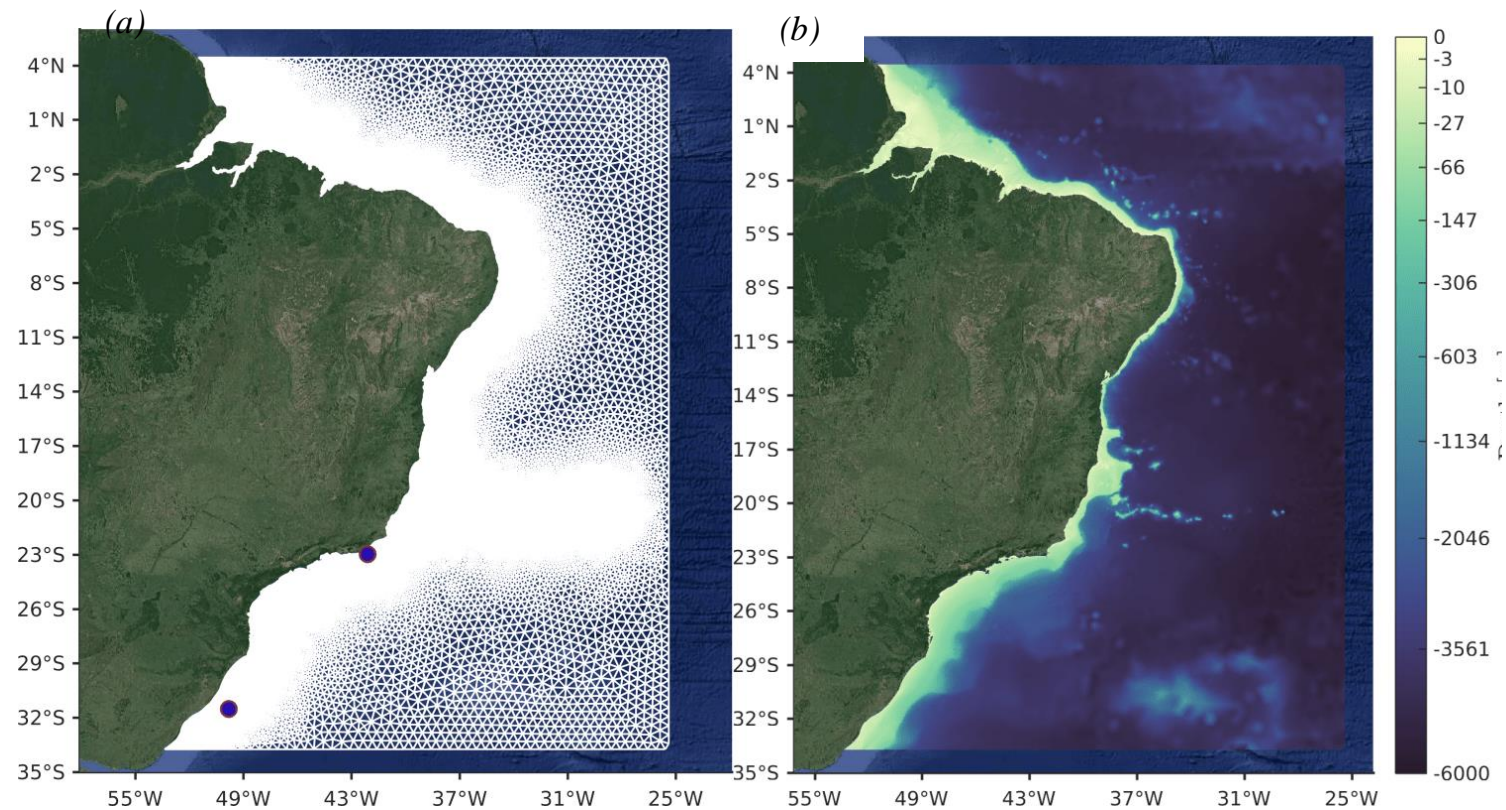

Figura 1: Discretization of spatial domain (a) and bathymetry of the studied region (b). The blue dots represent the areas used for validation.

To realize the simulations, the TOMAWAC model was initialized from repose. In the oceanic boundaries were imposed the follow wave parameters: significant height (Hs), peak period (Tp) and peak direction (Dp), taken from the European Center for Medium-Range Weather Forecasts (ECMWF) database, generated by the model ERA Interim. The superficial boundary was also forced with winds from ERA Interim database, considering temporal resolution of 6 hours and spatial resolution of $0.75^{\circ}$.

The longshore sediment transport rates were calculated with equations that have been developed and calibrated by some scientists. For this study, the LST rates were estimated considering sedimentary characteristics, waves parameters and beach profile information, to apply in the formulations proposed by CERC (1984) [4] and Kamphuis (1991) [5].

\subsection{CERC Model}

According to Equation 1, the CERC (1984) [4] formula calculates the LST rates in $\mathrm{m}^{3} / \mathrm{s}$ :

$$
Q v=\frac{K \rho_{a} g^{1 / 2} H_{s, b}{ }^{5 / 2} \sin \left(2 \alpha_{b}\right)}{16\left(\gamma_{b}^{\frac{1}{2}}\right)\left(\rho_{s}-\rho_{a}\right)(1-p)}
$$

where $\rho \mathrm{a}$ is the sea water density (considered $\left.1025 \mathrm{~kg} / \mathrm{m}^{3}\right), \mathrm{g}$ is the gravitational acceleration $(9.81$ $\left.\mathrm{m} / \mathrm{s}^{2}\right), \mathrm{Hs}, \mathrm{b}$ is the significant wave height at the break line $(\mathrm{m}), \alpha \mathrm{b}$ is the wave incidence angle at the breaker line (degrees), $\gamma_{\mathrm{b}}$ is the breaker parameter, $\rho \mathrm{s}$ is the sediment density (considered 2650 $\mathrm{kg} / \mathrm{m}^{3}$ ) and $\mathrm{p}$ is the sediment porosity (considered 0.4 ).

In addition, $\mathrm{K}$ is a dimensionless coefficient that has been defined by the Shore Protection Manual [4] equal to 0.39 for the United States beaches. However, the imposition of this coeficient becomes more reliable if it is calibrated with parameters and features of each region studied. For this study, the coefficient $\mathrm{K}$ was calculated considering the formulations proposed by Kamphuis et al. (1986) [7], del Valle et al. (1994) [8] and Mil-Homens et al. (2013) [9], besides the constant value 0.39 .

- Constant value recommended by CERC (1984) [4]:

$$
\mathrm{K}=0.39
$$

- Formulation proposed by Kamphuis et al. (1986) [7]: 


$$
K \operatorname{sig}=0.022 \sqrt{\frac{\gamma_{b} H_{s, b}}{D_{50}}}
$$

- Formulation proposed by del Valle et al. (1994) [8]:

where $0.44 \mathrm{~mm}<\mathrm{D}_{50}<1.5 \mathrm{~mm}$.

$$
K r m s=1.4 e^{-2.5 D_{50}}
$$

- Formulation proposed by Mil-Homens et al. (2013) [9]:

where $\mathrm{L}_{0}$ is the wave length (m).

$$
K r m s=\left[2237.7\left(\frac{H_{s, b}}{L_{0}}\right)^{1.45}+4.505\right]^{-1}
$$

\subsection{Kamphuis Model}

According to Equation 5, the Kamphuis (1991) [5] formula calculates the LST rates in $\mathrm{m}^{3} / \mathrm{year}$ :

$$
Q v=6.4 \times 10^{4}\left(H_{s, b}\right)^{2}\left(T_{p}\right)^{1.5}\left(m_{b}\right)^{0.75}\left(D_{50}\right)^{-0.25}\left[\sin ^{0.6}\left(2 \alpha_{b}\right)\right]
$$

where $\mathrm{Tp}$ is the wave peak period, and $\mathrm{mb}$ the slope of the beach profile at the break line.

\section{VALIDATION}

The TOMAWAC was validated in the Brazilian Continental Shelf by comparing the results of the model with the data measured by Programa Nacional de Bóias (PNBOIA). Time series of significant height were analyzed, during the year of 2012, to carry out the validation in two different places. The buoys are located in the Brazilian Coast in Rio Grande - Rio Grande do Sul and Cabo Frio - Rio de Janeiro at $200 \mathrm{~m}$ depth, as shown in Figure 1.

Different metrics were tested to quantify the comparison between the modeled and buoy data. These metrics were previously used in similar works as Hallak et al. (2011) [10] and Teegavarapu et al. (2012) [11]. The RMSE expresses the magnitude of the error of the model (in module) and the Bias measures the mean deviation between the buoy and the modeled data. Table 1 shows the computed values to the significant height for both sites: Rio Grande (RG) and Cabo Frio (CF).

Table 1: Statistical parameters to compare TOMAWAC model and buoy data.

\begin{tabular}{ccccc} 
& \multicolumn{2}{c}{ RIO GRANDE } & \multicolumn{2}{c}{ CABO FRIO } \\
\hline PARAMETER & TOMAWAC & PNBOIA & TOMAWAC & PNBOIA \\
\hline Height Average (m) & 2.3808 & 2.3588 & 1.1544 & 1.3505 \\
\hline Standard Deviation (m) & 1.0809 & 0.8439 & 0.5831 & 0.6936 \\
\hline RMSE (m) & \multicolumn{2}{c}{0.8008} & \multicolumn{2}{c}{0.5171} \\
\hline BIAS & \multicolumn{2}{c}{0.0054} & \multicolumn{2}{c}{0.1959} \\
\hline
\end{tabular}

Bias values nearly to zero shows that the model data are similar to observed data. In other words, the results are not underestimate or overestimate. For the RMSE it is possible to observe that in Cabo Frio the values resulted a few high, but this is considered acceptable due to the difference between the model and the buoy data be squared, what would cause higher RMSE values.

For the LST validation, the formulas proposed by CERC (1984) [4] and Kamphuis (1991) [5] were applied in four points of the Brazilian Coast, and compared to previous studies related to this subject (Table 2). 
Table 2: Validation of longshore sediment transport ( $\left.\mathrm{m}^{3} / \mathrm{ano}\right)$. The negative values indicate that the dominant direction of sedimentary transport is southwards.

CERC (1984)

\begin{tabular}{ccccccc}
\hline $\begin{array}{c}\text { STUDY } \\
\text { AREA }\end{array}$ & Recom. & $\begin{array}{c}\text { Kamphuis } \\
\text { et } \\
\text { al.(1986) }\end{array}$ & $\begin{array}{c}\text { del Valle } \\
\text { et } \\
\text { al.(1994) }\end{array}$ & $\begin{array}{c}\text { Mil- } \\
\text { Homens } \\
\text { et al.(2003) }\end{array}$ & $\begin{array}{c}\text { Kamphuis } \\
(\mathbf{1 9 9 1})\end{array}$ & $\begin{array}{c}\text { Previous } \\
\text { Studies }\end{array}$ \\
\hline $\begin{array}{c}\text { Cassino }- \\
\text { RS }\end{array}$ & -1925700 & -438540 & - & -295050 & -595430 & 1650 \\
\hline $\begin{array}{c}\text { Cibratel - } \\
\text { SP }\end{array}$ & -1654000 & -356760 & - & -296940 & -521410 & -400000 \\
\hline $\begin{array}{c}\text { Natal - } \\
\text { RN }\end{array}$ & 698830 & 26905 & - & 99651 & 84501 & 587211 \\
\hline $\begin{array}{c}\text { Galinhos - } \\
\text { RN }\end{array}$ & 662010 & 20092 & - & 99042 & 44963 & 185839 \\
\hline
\end{tabular}

The point in the Southern Region, in Rio Grande do Sul state, nearly the Cassino Beach, show values of LST ranged between $295050 \mathrm{~m}^{3} /$ year to $1925700 \mathrm{~m}^{3} /$ year. Applying the CERC (1984) [4] formula, the value resulted closer to the study by Lima and Toldo (2002) [12], where the authors found $1650379 \mathrm{~m}^{3} /$ year. These authors used a methodology different from those used in this article, as well as a much shorter data period, which explains the differences in the rates. In addition, drifting to the south, as opposed to previous studies in the region, indicates that the boundary conditions imposed on TOMAWAC may be influencing the results. Therefore, it was decided not to include in these analyzes the northern and southern regions of Brazil, since these would be the most affected by this limitation.

In relation to the point located in the Southeast Region, on the coast of São Paulo, in Cibratel, the transport rates calculated with the CERC (1984) [4] formula, with the K calibrated by Kamphuis et al. (1986) [7], approached the results of the study of Araújo and Alfredini (2001) [13]. The values resulted in $356760 \mathrm{~m}^{3} /$ year and $400000 \mathrm{~m}^{3} / \mathrm{year}$, respectively, being considered similar, although the authors applied another methodology, different mean diameter of sediments and data of only 3 years. In addition, drift from North to South validated the point analyzed.

For the Northeast region, the point choose was in Natal, in Rio Grande do Norte state. This site was compared between the study of Araújo (2015) [14] and the results by CERC (1984) [4] formula, which showed rates of approximately $698830 \mathrm{~m}^{3} /$ year and $587211 \mathrm{~m}^{3} / \mathrm{year}$, respectively, with drift towards South-North, giving the validity of the data obtained.

Finally, in Galinhos - Rio Grande do Norte state, the longshore sediment transport rates resulted similar in order of magnitude, comparing the formulation proposed by CERC (1984) [4], with K calibrated by Mil-Homens et al. (2013) [9], and the study of Marcelino et al. (2018) [15]. The calculation resulted rates of $99042 \mathrm{~m}^{3} /$ year and $185839 \mathrm{~m}^{3} /$ year, respectively. The drift dominant direction transport was from East to West for both studies.

The validation showed that the longshore sediment transport rates resulted similar in order of magnitude and dominant direction of littoral drift in relation to previously studies. Thus, for the present study, the longshore sediment transport was calculated in different points along the Brazilian Coast, and was considered a specific formula and sediment diameter for each section, as defined previously.

\section{RESULTS AND DISCUSSION}

The results presented in this section are derived from a 37-year wind-generated wave simulation between 1979 and 2015. Initially, the obtained results are presented as mean fields for the variables significant height, peak period and angle of incidence of the waves, calculated for the entire study region. These wave parameters were later used in the longshore sediment transport calculation.

The Figure 2 (a) shows the mean values of the significant wave height across the Brazilian Continental Shelf, with the maximum values reaching around $2.1 \mathrm{~m}$. In contrast, Figure 2 (b) shows 
the mean values of the peak period of the waves, ranging from 5 to $11 \mathrm{~s}$, as shown in the color bar. In addition, Figure 2 (c) shows the mean direction of the wave incident (in degrees), as shown in the color bar, where $0^{\circ}$ for $-90^{\circ}$ the waves came from the Southeast, while $0^{\circ}$ to $90^{\circ}$ from the Northeast. The angle of incidence of the waves is considered one of the most relevant parameters to determine the direction of longshore sediment transport, since the waves are the main ones responsible for the transport of coastal sediments, promoting processes of erosion and accumulation [16].

(a)

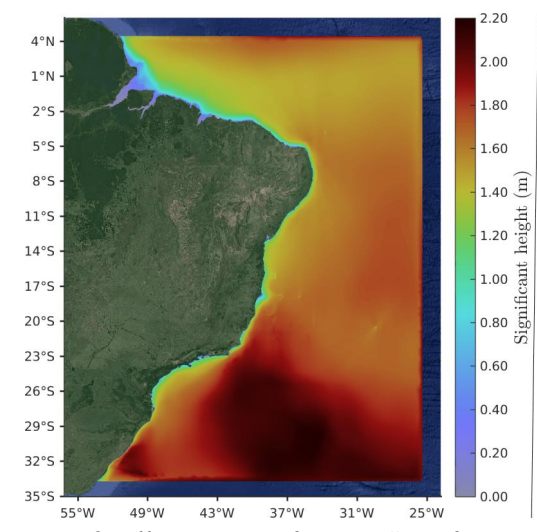

(b)

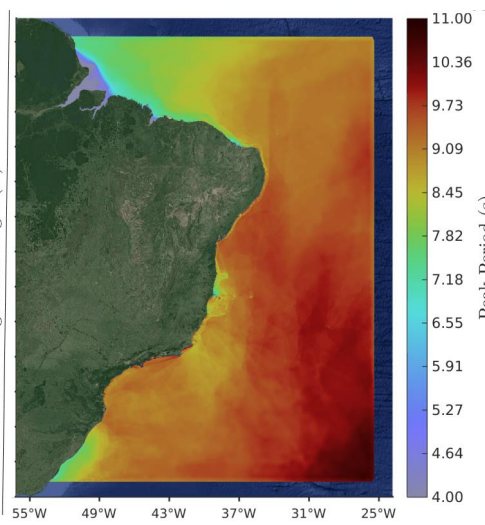

(c)

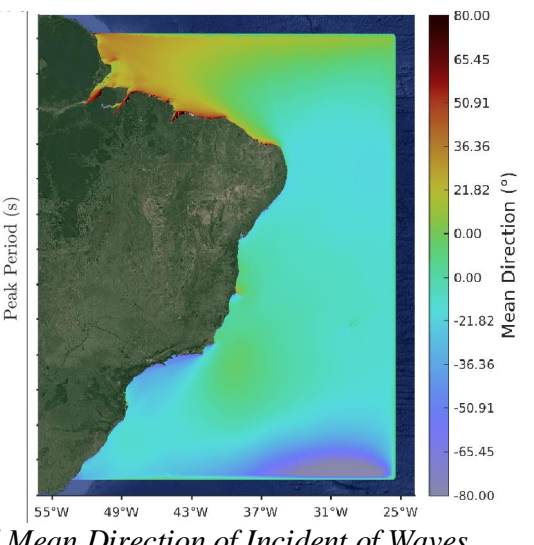

(c).

The results showed that the highest mean values of significant wave height occur in the South Region and in the vicinity of Cabo Frio, in Rio de Janeiro, where the values reach $1.8 \mathrm{~m}$. In the sector between Cabo de Santa Marta, in Santa Catarina state and Cabo Frio, there is a significant reduction in the significant wave height for $1.4 \mathrm{~m}$. These findings are in agreement with the studies carried out by Araújo et al. (2003) [17] and Contestabile et al. (2015) [18] on the Island of Santa Catarina, and by Oleinik et al. (2017) [19] on the South-Southeast Brazilian Platform. Tessler and Goya (2005) [20] also stated that the waves in the south and southeast vary in a mean height from 1 to $4 \mathrm{~m}$, with mean period of 10 for $16 \mathrm{~s}$.

In the regions that covers the Northeast and North of Brazil, it was possible to observe lower values in comparison to the South, where the mean significant wave height reaches approximately 1.4 and $1 \mathrm{~m}$, respectively. An exception occurs close to Cabo de São Roque, where it is possible to observe waves with significant height up to $1.6 \mathrm{~m}$. Silva et al. (2000) [21] calculated the wave parameters in Fortaleza, Ceará state, and noted that the significant wave height reaches between 1 to $1,5 \mathrm{~m}$, which agrees with the results of the present study.

In relation to the mean peak period of waves in the study region, a great similarity was observed throughout the Brazilian Shelf, with values about $9.5 \mathrm{~s}$, which are derived from distant storms and can be classified as Swell. In the state of Rio Grande do Sul and on the southern coast of Bahia, a reduction in the wave period is perceptible as the waves approach the coast, ranging from 9 to $6 \mathrm{~s}$. These waves with shorter periods are generated by the effect of the local winds that blow on the sea, and are called Sea. In the northern regions, mean wave periods are lower in relation to the other regions, reaching the maximum of $8 \mathrm{~s}$ and about $7 \mathrm{~s}$ near the coastline. These results are similar to the study of Pianca et al. (2010) [22], which analyzed the wave climate in the Brazilian Coast region, even as Araújo et al. (2003) [17] and Contestabile et al. (2015) [18] on Santa Catarina Island, and Araújo and Alfredini (2001) [13] on the coast of São Paulo.

In relation to the longshore sediment transport, the study region was sectioned in five parts, being considered a specific formula for each sector, with the corresponding sediment diameter, as presented next. It is noteworthy that due to the proximity of the north and south regions with the boundary conditions of the numerical mesh, it was necessary to disregard these sites in the study.

Figure 3 shows the passage from (a) the north coast of Santa Catarina state to Cabo Frio, (b) Cabo Frio towards Belmonte (Bahia state), (c) Belmonte to Aracaju (Sergipe state), (d) Aracaju to Cabo de São Roque (Rio Grande do Norte state) and (e) Cabo de São Roque to Delta do Parnaíba (between the states of Maranhão and Piauí). The rates of longshore sediment transport were 
analyzed in some locations, indicating the predominant drift direction. The blue dots represent the validated areas and the color bar indicates the bathymetry of the location.
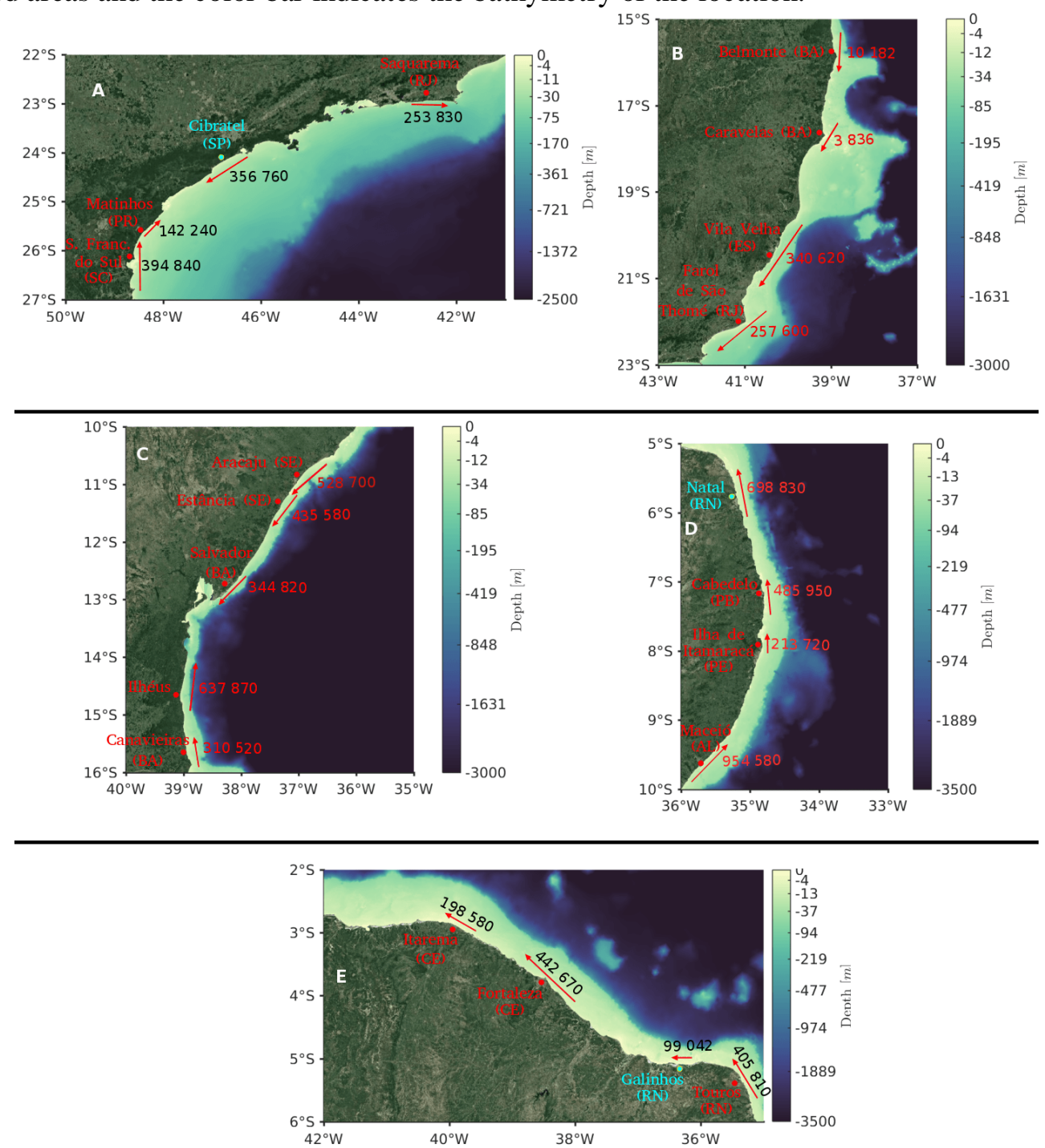

Figure 3: Representation of longshore sediment transport rates in $\mathrm{m}^{3} /$ year between the (a) Santa Catarina north coast towards Cabo Frio, (b) Cabo Frio towards Belmonte, (c) Belmonte to Aracaju, (d) Aracaju to Cabo de São Roque and (e) Cabo de São Roque to Delta do Parnaíba. The arrows indicate the direction and order of magnitude of the transport. The color bar represents the depth.

In the first frame, the mean sediment diameter is equal to $0.06 \mathrm{~mm}$ and corresponds to a mud/fine sand. In the second and third, it was considered $0.6 \mathrm{~mm}$, and a medium sand. In the other sentences, it was considered $2 \mathrm{~mm}$ and a coarser sand. The formula proposed by CERC (1984) [4], with K calibrated by Kamphuis et al. (1986) [7], was applied in the first frame. In the second and third frame, the coefficient K was calibrated by del Valle et al. (1994) [8]. This methodology was considered in these sectors because there is a restriction in sediment diameter, and these areas have not been validated. In the next segments, the CERC (1984) [4] formula was applied with coefficient K equal 0.39 and calibrated by Mil-Homens et al. (2013) [9], respectively.

Figure 3 (a) shows the Brazilian Continental Shelf between Laguna and Cabo Frio. This shelf is considerable wide, with a maximum of $230 \mathrm{~km}$ near Santos (São Paulo state), and a minimum of $80 \mathrm{~km}$ in Cabo Frio, according to Coutinho (2000) [23]. This author also affirmed that the slope in this region is smooth, reaching about $1 \mathrm{~m} / \mathrm{km}$. On the other hand, throughout the Cabo Frio and Belmonte sector, the author declared that there is a high variation of the wide in continental shelf, reaching the maximum of $246 \mathrm{~km}$ in Caravelas (Bahia state), and the minimum of $48 \mathrm{~km}$ nearby of the south of Regência (Espírito Santo state). The slope of this region is steeper, reaching approximately $0.3 \mathrm{~m} / \mathrm{km}$. 
The behavior of the mean sedimentary transport, in 37 years simulated, can be explained by the action of waves, which is the main forces for the occurrence of beach processes as erosion and deposition. Brazilian southeast coast, from Cabo Frio to the south region, according to Pianca et al. (2010) [22], it is reached by high waves generated by storms in the South Atlantic, with more energetic waves coming from the south quadrant. This confirms the dominant direction of the sedimentary transport to the northeast. Figure 2 (c) also corroborates with this information, showing angles near to $-30^{\circ}$ and so indicating that the predominant direction of the waves is the southeast.

In São Paulo coast, according with Araújo and Alfredini (2001) [13], the dominant direction of sedimentary transport is for southwest. This information can be explained due the coastline being directed northeast-southeast, with predominance of waves from Northeast and East by the action of Atlantic Tropical Cyclone.

In the next frame, between Cabo Frio and Belmonte, Figure 3 (b) shows that the drift is directed southwards, confirming the study of Tessler and Goya (2005) [20], that affirms that the most effective waves in sedimentary transport are generated by trade winds from the north quadrant. For the Southeast Region and the sector south of Bahia, the Figure 2 (c) shows that angles nearby to zero are predominant, with some points positive. This fact indicate that the waves are from the east and northeast, consenting with these authors.

The coastal sector between Belmonte and Cabo de São Roque, according to Martins and Coutinho (1981) [24], have a shelf break closer to $80 \mathrm{~m}$, so is considered

with a reduced width and a shallow depth in relation to the other sectors analyzed. In agreement with Coutinho (2000) [23], the shelf mean slope is about $1.7 \mathrm{~m} / \mathrm{km}$, with a maximum of $10 \mathrm{~m} / \mathrm{km}$ in the coast of Aracajú.

Figure 3 (c) shows that in the sector of Belmonte towards Aracaju the waves action is similar that between Cabo Frio and Belmonte. Figure 2 (c) corroborates with this fact, showing that in this segment the direction of the waves is predominantly from Northeast. In Ilhéus and Canavieiras, both in Bahia, occurs an exception due to the change in the orientation of the coastline.

The next frame, Figure 3 (d) shows the segment between Sergipe and Rio Grande do Norte state. In this sector, the dominant direction of the sedimentary transport is towards north, because the waves are generated by the eastern trade winds, without wave action being promoted by the meteorological fronts. Figure 2 (c) corroborates with this fact, showing that the incidence directions of the waves are negatives, and so these reach the coast from southeast.

Finally, Figure 3 (e) shows the sector between Cabo de São Roque and Delta do Parnaíba. According to Martins and Coutinho (1981) [24], this shelf has a width about $30 \mathrm{~km}$ close to Touros (Rio Grande do Norte state), and the shelf slope begins at a depth nearby $80 \mathrm{~m}$. In this sector, the winds action is associated to the eastern trade winds [20], so the waves are from east and northeast, accordance with the Figure 2 (c). Thus, it is possible to observe that all sediment transport is directed from east to west.

\section{CONCLUSION}

Applying the wind-generated waves model was possible to obtain the wave parameters and the annual rates of longshore sediment transport. The rates obtained in different sectors of the Brazilian Coast followed the trends presented in previous studies, and thus, different formulas were analyzed.

The results presented a big difference in the behavior of the wave climate throughout the Brazilian Continental Shelf, which can be explained by the wide diversity in averages of significant wave height and incidence wave direction. Thereby, in a first moment, it was assumed that the sedimentary transport rates along the Brazilian Coast will present great variations too.

The segments where the longshore sediment transport rates resulted high are related to the sector between Alagoas and Rio Grande do Norte states, while the smallest rates occurred on the southern part of Bahia state. The high discrepancy in the results is associated to the sediments diameter and to the slope of the beach profiles, since there is an expressive variation throughout the Brazilian Coast. Besides, the formula considered more appropriate for each sector also influenced in the results. In this way, it is suggested that other points be considered for validation of the longshore sediment transport in future studies. 
Nevertheless, the sedimentary transport rates obtained in this study were similar with the results of previous studies. Thus, the present study contributes with data about the waves behavior and sediment transport in all Brazilian Coast, being useful in future projects of engineering that involves the sustainable management of the coastal zone.

\section{ACKNOWLEDGMENTS}

The authors would like to thanks the Coordenação de Aperfeiçoamento de Pessoal de Nivel Superior (CAPES) for the granting of scholarships, the Conselho Nacional de Desenvolvimento Científico e Tecnológico (CNPq) by the contract 304227/2016-1, the Fundação de Amparo à Pesquisa do Estado do Rio Grande do Sul (FAPERGS) by the contract 17/2551-0001 159-7, and the National Center for Supercomputing (CESUP) of Federal University of Rio Grande do Sul (UFRGS), who helped with the development of this study. Thank you also to the ECMWF by oceanographic and meteorological data used in the model boundary conditions, the consortium Open TELEMAC-MASCARET by providing the TELEMAC system charge and the National Laboratory of Scientific Computing (LNCC) by making use of the Supercomputer Santos Dumont.

\section{REFERENCES}

1. Muehe D. Panorama da erosão costeira no Brasil. Brasília: Ministério do Meio Ambiente (MMA); 2018. $72 p$.

2. Souza CRDG. A Erosão Costeira e os Desafios da Gestão Costeira no Brasil. Rev Gestão Costeira Integr. 2009 Mai;9(1):17-37.

3. Pitombeira EDS. Cálculo do Transporte Litorâneo de Sedimentos na Costa do Rio Grande do Sul, Tramandaí [thesis]. Porto Alegre (RS): Universidade Federal do Rio Grande do Sul; 1973. 263p.

4. CERC. Shore Protection Manual. Washington, D. C.: U.S. Army Coastal Engineering Research Center; 1984. 337p.

5. Kamphuis JW. Alongshore Sediment Transport Rate. J Waterway, Port, Coastal Ocean Eng. 1991 Nov;117(6):624.

6. Benoit M, Marcos F, Becq F. Development of a Third Generation Shallow-Water Wave Model with Unstructured Spatial Meshing. 25th International Conference on Coastal Engineering; 1996 Aug 465478; v25.25p. New York, doi: 10.9753/icce.

7. Kamphuis JW, Davies MH, Nairn RB, Sayao, OJ. Calculation of littoral sand transport rate. Coastal Eng. 1986 May;10(1):1-21, doi: 10.1016/0378-3839(86)90036-0.

8. del Valle R, Medina R, Losada MA. Dependence of Coefficient K on Grain Size. J. Waterway, Port, Coastal, Ocean Eng. 1994 Nov;119(5)568-574.

9. Mil-Homens J, Ranasinghe R, van Thiel de Vries JSM, Stive MJF. Reevaluation and Improvement of Three Commonly Used Bulk Longshore Sediment Transport Formulas. Coastal Eng. 2013 May;75(1)2939, doi: 10.1016/j.coastaleng.2013.01.004.

10. Hallak R, Pereira, AJ. Metodologia para Análise de Desempenho de Simulações de Sistemas Convectivos na Região Metropolitana de São Paulo com o Modelo ARPS: Sensibilidade a variações com os esquemas de advecção e assimilação de dados. Rev Bras Meteorol. 2011 Fev; 26(4)591-608.

11. Teegavarapu RSV. Floods in a Changing Climate: Extreme Precipitation. Cambridge: Cambridge University Press; 2012. 291 p. doi: 10.1017/CBO9781139088442.

12. Lima SF, Almeida LE, Toldo Júnior EE. Estimativa da Capacidade de Transporte Longitudinal de Sedimentos a partir de Dados de Ondas para a Costa do Rio Grande do Sul. Pesq Geoc. 2002 Mai;28(2)99-107.

13. Araújo R, Alfredini PO. Cálculo do Transporte de Sedimentos Litorâneo: Estudo de Caso das Praias de Suarão e Cibratel (Município de Itanhaém, São Paulo). Rev Bras Recursos Hídricos. 2001, Fev;6(2)1528.

14. Araújo DJC. Transporte Longitudinal De Sedimento Na Zona Costeira de Natal/RN [dissertação]. Natal (RN): Universidade Federal do Rio Grande do Norte; 2015. 184 p.

15. Marcelino AMT, Pinheiro LRSG, Costa JRS. Planejamento participativo para a gestão da orla marítima de Galinhos/RN, nordeste brasileiro, com apoio de sensores remotos e modelagem costeira. Rev Desenv Meio Ambiente. 2018 Nov;44(1)118-139.

16. Griggs GB, Trenhaile AS. Coastal Cliffs and Plataforms. 1nd ed. Cambridge: Cambridge University Press; 1994. Chapter 4, Coastal evolution late quaternary shoreline morphodynamics; p. 450. 
17. Araújo CES, Franco D, Melo Filho E, Pimenta FM. Wave Regime Characteristics of the Southern Brazilian Coast. Sixth International Conference on Coastal and Port Engineering in Developing Countries; 2003 Jan 30-45; Colombo, Sri Lanka.

18. Contestabile P, Ferrante V, Vicinanza D. Wave Energy Resource along the Coast of Santa Catarina (Brazil). Energies. 2015 Fev;8(12):14219-14243. doi:103390/en81212443.

19. Oleinik PH, Marques WC, Kirinus EP. Evaluation of the Seasonal Pattern of Wind-DrivenWaves on the South-Southeastern Brazilian Shelf. Defect and Diffusion Forum 2017 Mai;370(1)141-151. Doi:10.4028/www.scientific.net/DDF.370.141.

20. Tessler MG, Goya SC. Processos Costeiros Condicionantes do Litoral Brasileiro. Rev Depart Geogr. 2005 Ago;17(1)11-23. doi.org./107154/RDG.2005.0017.0001.

21. Silva A, Leitão J, Dias A, Coli A, Fachin S, Lontra G. Evaluation of Sediment Transport Processes in the Port of Fortaleza - Brazil. International conference on coastal engineering; 2000 Nov 3742-3754; Sydney, Austrália.

22. Pianca C, Mazzini PLF, Siegle E. Brazilian Offshore Wave Climate based on NWW3 Reanalysis. Brazilian J Oceanogr. 2010 Apr;58(1), 53-70. Doi:10.1590/S1679-87592010000100006.

23. Coutinho PN. Levantamento do Estado da Arte da Pesquisa dos Recursos Vivos Marinhos do Brasil. Brasília: Programa de Avaliação do Potencial Sustentável de Recursos Vivos na Zona Econômica Exclusiva; $2000.75 \mathrm{p}$.

24. Martins LR, Coutinho PN. The Brazilian Continental Margin. Earth Science Rev. 1981 Apr;17(1)87-107. 